\title{
Quality of Life among University Students with Premenstrual Syndrome
}

\section{Qualidade de vida entre estudantes universitárias com síndrome pré-mesntrual}

\author{
Fernanda Figueira Victor ${ }^{1}$ Ariani Impieri Souza ${ }^{1,2}$ Cynthia Danúbia Tavares Barreiros ${ }^{1}$ \\ João Lucas Nunes de Barros ${ }^{1}$ Flavia Anchielle Carvalho da Silva ${ }^{1,2}$ Ana Laura Carneiro Gomes Ferreira ${ }^{2 \odot}$ \\ ${ }^{1}$ Faculdade Pernambucana de Saúde, Recife, PE, Brazil \\ 2 Department of Women's Health Research, Instituto de Medicina \\ Integral Professor Fernando Figueira, Recife, PE, Brazil \\ Address for correspondence Ana Laura Carneiro Gomes Ferreira, \\ Departamento de Pesquisa em Saúde da Mulher, Instituto de Medicina \\ Integral Professor Fernando Figueira. Rua dos Coelhos, 300 Boa Vista, \\ 50.070-550, Recife, PE, Brazil \\ Rev Bras Ginecol Obstet 2019;41:312-317. \\ (e-mail: analaura@imip.org.br).
}

\begin{abstract}
Keywords

- medical student

- menstruation disturbances

- premenstrual dysphoric disorder

- premenstrual syndrome

- quality of life
\end{abstract}

Resumo
Objective To evaluate the quality of life among university students with premenstrual syndrome (PMS).

Methods The cross-sectional study was conducted at the Faculdade Pernambucana de Saúde, in Recife, Brazil, between August 2016 and July 2017. Sociodemographic, gynecological, and lifestyle variables, and PMS occurrence, were investigated among 642 students. The short form of the World Health Organization Quality of Life (WHOQOL Bref) questionnaire was used to evaluate four domains of the quality of life of the students: physical, mental, social relationships, and environmental. The American College of Obstetricians and Gynecologists' criteria were used to define PMS. Results Of the 642 students, $49.9 \%$ had PMS, 23.3\% had mild PMS and 26.6\% had premenstrual dysphoric disorder (PMDD). Most of the students were between 18 and 24 years old, had regular menstrual cycles, and practiced physical activity. Regarding the physical and mental domains of the WHOQOL-Bref questionnaire, a statistically significant difference was observed between the students who did not have and those who had mild or PMDD $(p<0.001)$. A difference was also found between the students who did not have PMS and those who had mild PMS in the social relationships $(p=0.001)$ and environmental domains $(p=0.009)$.

Conclusion Mild PMS and PMDD are prevalent among university students on healthrelated courses, and the syndrome can affect the students' self-assessment of all the domains of quality of life.

Objetivo Avaliar a qualidade de vida entre estudantes universitárias com síndrome pré-menstrual (SPM).

\footnotetext{
(1)Ana Laura Carneiro Gomes Ferreira's ORCID is https://orcid.org/ 0000-0001-9172-6162.
}

received January 2, 2019 accepted April 4, 2019
DOI https://doi.org/ 10.1055/s-0039-1688709. ISSN 0100-7203.
Copyright $\odot 2019$ by Thieme Revinter Publicações Ltda, Rio de Janeiro, Brazil
License terms

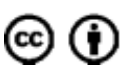


Métodos Foi realizado um estudo transversal na Faculdade Pernambucana de Saúde, em Recife, no período de agosto de 2016 a julho de 2017. Foram investigadas variáveis sociodemográficas, ginecológicas, estilo de vida e a ocorrência de SPM entre 642 estudantes. Foi utilizada a forma abreviada do questionário de Qualidade de Vida da Organização Mundial da Saúde (WHOQOL Bref, na sigla em inglês) para avaliar quatro domínios da qualidade de vida: físico, mental, social e meio ambiente. Para a definição de SPM, foram considerados os critérios do Colégio Americano de Obstetras e Ginecologistas. Resultados Das 642 estudantes, 49,9\% apresentaram SPM, sendo 23,3\% SPM na forma

Palavras-chave

- estudantes de medicina

- distúrbios menstruais

- síndrome prémenstrual

- transtorno disfórico pré-menstrual

- qualidade de vida leve e $26,6 \%$, transtorno disfórico pré-menstrual (TDPM). A maioria das estudantes tinha entre 18 e 24 anos de idade, possuia ciclos menstruais regulares e praticava atividade física. Em relação aos domínios físico e mental do WHOQOL-Bref, observou-se diferença estatisticamente significante entre as estudantes que não apresentavam SPM e as que apresentavam SPM, tanto a forma leve quanto o TDPM $(p<0,001)$. Também foi encontrada diferença no domínio "relações sociais" e "meio ambiente" entre aquelas que não tiveram TPM e as que tiveram TPM leve ( $p=0,001$ e $p=0,009$, respectivamente). Conclusão A SPM leve e o TDPM têm alta prevalencia entre estudantes universitárias da área de saúde e pode influenciar a autoavaliação das estudantes em todos os domínios da qualidade de vida.

\section{Introduction}

The global prevalence of premenstrual syndrome (PMS) varies from 75 to $85 \%$, and it is defined by a variety of physical, behavioral, and emotional symptoms that occur during the luteal phase of the menstrual cycle. ${ }^{1}$ These symptoms occur in a cyclical form and disappear within a few days after the menses. Premenstrual syndrome can negatively affect the daily activities of women who are of reproductive age. ${ }^{2}$ Some of the physical symptoms are breast enlargement and sensitivity, edema, weight gain, headache, and fatigue. In addition, anxiety, irritability, emotional lability, and changes in appetite and sleep are features of the mood swings. ${ }^{2,3}$

There is no consensus regarding the diagnostic criteria for PMS because of the subjectivity of many symptoms, the use of self-reports, and the interference of psychological components as well as the lack of specific tests that confirm its diagnosis. ${ }^{1}$ Thus, it has been suggested that the American College of Obstetricians and Gynecologists' criteria are used for diagnosis. ${ }^{1,4}$

Mild PMS is characterized by up to three physical or emotional symptoms, which are sometimes not perceived by women as being PMS. The most severe form of PMS, premenstrual dysphoric disorder (PMDD), is characterized by more severe symptoms that are associated with psychological dominance and intense mood swings, which may exacerbate and/or weaken the existing symptoms. ${ }^{1,4,5}$

The etiology of PMS is multifactorial, and it may be influenced by hormonal, genetic, environmental, and sociocultural factors. ${ }^{4,6}$ Other factors related to the menstrual cycle may contribute to the manifestation of PMS, such as the age of menarche, menstrual flow, and other menstruation disturbances. Besides these, PMS may adversely affect physical and social activities and interfere with interpersonal relationships and work productivity, consequently influencing the quality of life. ${ }^{6,7}$

Quality of life refers to an individual's perception of their position in life, in the context of the culture and social values in which they live, in addition to their goals, expectations, standards, and concerns. ${ }^{7}$ Quality of life can also be identified as synonymous with happiness, personal satisfaction, the conditions of life, and lifestyle.,

Approximately 50 to $80 \%$ of women of reproductive age have some symptoms of PMS, and around 3 to $8 \%$ will experience an extreme mood swing, which interferes with their lifestyle and may be severe enough to decrease their self-esteem, as well as affect their attendance at school and work. ${ }^{2,10}$

Due to the multidimensional aspect of the quality of life, as well as the high prevalence of PMS and the multiplicity of the diagnostic criteria, it is important to study the repercussions that PMS can have on the social and academic life of young women. Therefore, the present study aimed to identify the effect of PMS on the quality of life of university students in the northeast of Brazil.

\section{Methods}

A cross-sectional study was conducted between August 2016 and July 2017 that involved students from the medical, nursing, physiotherapy, psychology, pharmacy, and nutritional courses at a university in Recife City, Brazil. All students over 18 years old with regular menses were invited to participate in this study by personal contact. Of the 730 eligible students, 81 were excluded because they reported having a previous psychiatric disorder or because they did not provide sufficient information about the diagnosis of PMS. We administered selfreported questionnaires about sociodemographic, gynecological, and lifestyle variables, and the diagnostic criteria of PMS 
and PMDD to 649 students. We defined mild PMS as the presence of at least one of the following symptoms: depressive mood, anxiety, affective lability, irritability, decreased interest in daily activities, lethargy, change in appetite, sleep disturbance, feeling out of control, or physical symptoms, such as tenderness/swelling of the breasts, joint or muscle pain, and weight gain. ${ }^{1,4}$ Both the physical symptoms and mood changes should have been present in at least three cycles, have disappeared after menstruation, and have been associated with significant personal suffering. To have a diagnosis of PMS, the women should not have had any psychiatric disorders. ${ }^{1,4}$

For the PMDD diagnosis, the fifth edition of the Diagnostic and Statistical Manual of Mental Disorders' (DSM-5) criteria were used. ${ }^{5}$ The DSM-5 defines PMMD as the presence of at least five of the emotional, mood, behavioral, and physical symptoms as described above, with one of them necessarily being of emotional origin, and the symptoms occurring in the majority of menstrual cycles.

Quality of life was evaluated using the short form of the World Health Organization Quality of Life (WHOQOL-BREF) questionnaire (the validated version in Brazil). ${ }^{11}$ This questionnaire consists of 26 questions. The first two questions (questions 1 and 2) about the global quality of life relate to the self-perception of life and satisfaction with personal health. The remaining 24 questions are distributed among facets of four structural domains: physical, mental, social relationships, and environmental. Responses are graded from 1 to 5 and adjusted for each domain. ${ }^{11}$ The domains and facets are described in - Chart 1.

We compared the means of the quality of life scores between two groups of students: those who did have or did not have mild PMS or PMDD, and those who had mild PMS or had PMDD. We considered all four structural domains and the first two questions in the analyses. The Stata v.12 program (StataCorp LP, College Station, TX, USA) was used. Analysis of variance (ANOVA) was used to compare and test the equality of the means between the groups. Pairwise comparisons were performed using the Tukey method. In both tests, we used the significance level of $5 \%(p<0.05)$.

The study was approved by the Research Ethics Committee of the Faculdade Pernambucana de Saúde (CAAE number: 58825516.8.0000.5569). All the participants signed an informed consent form.

\section{Results}

Of the 649 students, 151 (23.3\%) had mild PMS and 173 (26.6\%) had PMDD. Most women were between 18 and 24 years old (540; 83.2\%), lived in the city of Recife (510; 78.6\%), reported having no partner (598; 92.1\%), were unemployed (548; 84.4\%), and lived with their parents (500; 77\%), as shown in - Table 1.

The women had their menarche between 8 and 12 years old $(414 ; 63.8 \%)$, and 396 of them $(61 \%)$ were sexually active. Almost half of them $(292 ; 45 \%)$ reported not using any contraceptive method, 242 (37.3\%) used hormonal methods, and 467 (71.9\%) had regular menses (-Table 2 ).

We observed that 431 (66.4\%) of the subjects reported consuming alcoholic beverages, and 363 (55.9\%) stated that
Chart 1 Domains and facets of the short form of the World Health Organization Quality of Life questionnaire

\begin{tabular}{|l|l|}
\hline Domains & Facets \\
\hline Physical & $\begin{array}{l}\text { Pain and discomfort } \\
\text { Energy and fatigue } \\
\text { Sleep and rest } \\
\text { Mobility } \\
\text { Activities of daily living } \\
\text { Dependence on medication } \\
\text { or treatments } \\
\text { Work capacity }\end{array}$ \\
\hline Mental & $\begin{array}{l}\text { Positive feelings } \\
\text { Thinking, learning, memory, } \\
\text { and concentration } \\
\text { Self-esteem } \\
\text { Body image and appearance } \\
\text { Negative feelings } \\
\text { Spirituality/religion/personal beliefs }\end{array}$ \\
\hline Social & $\begin{array}{l}\text { Personal relationships } \\
\text { Social support } \\
\text { Sexual activity }\end{array}$ \\
\hline Environmental & $\begin{array}{l}\text { Physical security and protection } \\
\text { Home environment } \\
\text { Financial resources } \\
\text { Health and social care: availability } \\
\text { and quality } \\
\text { Opportunities to acquire new information } \\
\text { and skills } \\
\text { Participation in recreation/leisure } \\
\text { opportunities } \\
\text { Physical environment: pollution/noise/ } \\
\text { traffic/climate } \\
\text { Transport }\end{array}$ \\
\hline
\end{tabular}

Source: Fleck et al. ${ }^{11}$

they practiced some physical activity two or more times per week (-Table $\mathbf{3}$ ).

When we analyzed the quality of life, there was a statistically significant difference in the physical and mental domains between the students who did not have PMS and those who had mild PMS or PMDD $(p<0.001)$. We also observed a statistically significant difference between students without PMS and those with mild PMS in the social relationships ( $p=0.010$ ) and environmental domains ( $p$ 1/4 0.009). In Question 1 of the questionnaire, we observed a statistically significant difference between those who did not have PMS and those who had PMDD ( $p=0.005)$, but this difference was not observed for Question 2 (-Table 4).

\section{Discussion}

The population of this study was young university students, between 18 and 24 years old, who lived with their parents and were unemployed, which is similar to other studies conducted in Brazil. ${ }^{7,12,13}$ About half of the women were sexually active and used some kind of contraceptive method, mainly the combined oral contraceptive (COC). Carvalho et $\mathrm{al}^{13}$ also observed that $60.7 \%$ of the women with PMS had used the COC. This could occur because anovulatory cycles help to reduce PMS symptoms. However, a study conducted by Antunes et $\mathrm{al}^{14}$ involving university students in the city of São Paulo did not 
Table 1 Sociodemographic profile of the students on healthrelated courses

\begin{tabular}{|l|l|l|}
\hline Variables & $N=649$ & $\%$ \\
\hline Age (years) & & \\
\hline Mean 22.1 (SD 4.4) & & \\
\hline $18-24$ & 540 & 83.2 \\
\hline $25-35$ & 90 & 13.9 \\
\hline$>35$ & 13 & 2.0 \\
\hline Not informed & 6 & 0.9 \\
\hline City & & \\
\hline Recife & 510 & 78.6 \\
\hline RMR* & 117 & 18.0 \\
\hline Rural area & 21 & 3.2 \\
\hline Unknown & 1 & 0.2 \\
\hline Marital status & & \\
\hline Single & 598 & 92.1 \\
\hline With partner & 49 & 7.5 \\
\hline Unknown & 2 & 0.4 \\
\hline Employed & & \\
\hline Yes & 94 & 14.5 \\
\hline No & 548 & 84.4 \\
\hline Unknown & 7 & 0.7 \\
\hline Live with their parents & 500 & \\
\hline Yes & 149 & \\
\hline No & & \\
\hline
\end{tabular}

Abbreviations: RMR, Metropolitan region of Recife; SD, standard deviation.

Table 2 Reproductive profile of the students in health-related courses

\begin{tabular}{|l|l|l|}
\hline Variables & $N=649$ & $\%$ \\
\hline Age at menarche (years) & & \\
\hline $8-12$ & 414 & 63.8 \\
\hline $13-20$ & 224 & 34.5 \\
\hline Unknown & 11 & 1.7 \\
\hline Sexually active & & \\
\hline Yes & 396 & 61.0 \\
\hline No & 251 & 38.7 \\
\hline Unknown & 2 & 0.3 \\
\hline Contraceptive method & & \\
\hline None* & 292 & 45.0 \\
\hline Hormonal & 242 & 37.3 \\
\hline Non-hormonal & 98 & 15.1 \\
\hline Unknown & 17 & 2.6 \\
\hline Regular cycles & & \\
\hline Yes & 467 & 71.9 \\
\hline No & 177 & 27.3 \\
\hline Unknown & 5 & 0.8 \\
\hline
\end{tabular}

*Including those who were not sexually active.
Table 3 Lifestyle of the students in health-related courses

\begin{tabular}{|l|l|l|}
\hline Variables & $N=649$ & $\%$ \\
\hline Alcoholic beverage consumption & \multicolumn{2}{|l|}{} \\
\hline Yes & 431 & \\
\hline No & 218 & 33.6 \\
\hline Frequency of alcohol consumption* $(N=431)$ & 29.7 \\
\hline Weekly & 128 & 28.5 \\
\hline Monthly & 123 & 41.5 \\
\hline Rarely & 179 & 0.3 \\
\hline Unknown & 1 & \\
\hline Physical activity & & 55.9 \\
\hline More than twice a week & 363 & 43.5 \\
\hline None/rarely & 282 & 0.6 \\
\hline Unknown & 4 & \\
\hline
\end{tabular}

*Only for the 431 participants that reported their alcoholic beverage consumption.

observe any decrease in PMDD symptoms in students who used the COC. Corroborating these findings, Bianco et al ${ }^{15}$ suggested that the use of the COC may be associated with worsening depression in women predisposed to this condition.

The consumption of chocolate, caffeine, and alcohol has been related to PMDD ${ }^{14}$ and, in this study, more than half of the students reported consuming alcohol. Sahin et $\mathrm{al}^{8}$ demonstrated that the PMS prevalence among university students in Turkey was significantly higher among the consumers of coffee, chocolate, and fatty and salty foods; however, we do not have scientific evidence regarding the role of these nutrients in the etiopathogenesis of the syndrome. ${ }^{16}$

Half of the students reported performing physical activity two or more times a week, which is similar to the data found in a study with Polish adolescents, ${ }^{17}$ but, in the Polish study, there was no positive association between physical activity and PMS symptoms. ${ }^{17}$ In addition, the Sahin et al ${ }^{8}$ study in Turkey found an even greater frequency of PMS in women who practiced physical activity regularly, which suggests that the physical activity would not have been sufficient to produce beneficial effects on PMS. Despite this, the practice of regular exercise (at least 30 minutes a day on most days of the week) has been widely recommended for reducing PMS symptoms. ${ }^{4,18,19}$

The prevalence of all forms of PMS (mild PMS and PMDD) in our study was $49.9 \%$, which is similar to other studies conducted with university students in Taiwan ${ }^{20}$ (39.8\%), Turkey ${ }^{8}$ (36.3\%), and $\operatorname{Iran}^{21}$ (39.4\%). On the other hand, our prevalence was lower than that of another Brazilian study, ${ }^{7}$ in which it was $72.6 \%$, which, in turn, is lower than in three other studies involving Polish students ${ }^{17}$ (76.4\%), Jordanian women ${ }^{3}$ (80.2\%), and Iranian medical students (94.6\%). ${ }^{22}$ These differences may occur due to the diagnostic criteria used to define PMS, as well as the use of these criteria in population groups with different demographic, sociocultural, and lifestyle characteristics. ${ }^{20,21,23}$

Similarly, the diagnosis of PMDD may vary according to the population studied in terms of whether it has been evaluated for other possible differential diagnoses, such as 
Table 4 Comparisons of the mean scores of the physical, mental, social relationships, and environmental domains, according to the presence of premenstrual syndrome

\begin{tabular}{|l|l|l|l|l|}
\hline \multirow{2}{*}{ Domains } & Without PMS & With mild PMS & With PMDD & $p^{*}$ \\
\cline { 2 - 5 } & Mean $\pm S D$ & Mean $\pm S D$ & Mean $\pm S D$ \\
\hline Physical & $3.8^{\mathrm{a}} \pm 0.5$ & $3.6^{\mathrm{b}} \pm 0.6$ & $3.6^{\mathrm{b}} \pm 0.5$ & $<0.001$ \\
\hline Mental & $3.8^{\mathrm{a}} \pm 0.5$ & $3.6^{\mathrm{b}} \pm 0.6$ & $3.6^{\mathrm{b}} \pm 0.5$ & $4.0^{\mathrm{ab}} \pm 0.7$ \\
\hline Social relationships & $4.0^{\mathrm{a}} \pm 0.6$ & $3.8^{\mathrm{b}} \pm 0.7$ & $3.6^{\mathrm{ab}} \pm 0.6$ & 0.010 \\
\hline Environmental & $3.7^{\mathrm{a}} \pm 0.6$ & $3.6^{\mathrm{b}} \pm 0.6$ & $3.7^{\mathrm{b}} \pm 0.4$ & 0.009 \\
\hline Mean score & $3.8^{\mathrm{a}} \pm 0.4$ & $3.6^{\mathrm{b}} \pm 0.5$ & $4.0^{\mathrm{b}} \pm 0.7$ & $<0.001$ \\
\hline Question 1 & $4.2^{\mathrm{a}} \pm 0.6$ & $4.1^{\mathrm{ab}} \pm 0.6$ & $3.7 \pm 0.9$ & 0.005 \\
\hline Question 2 & $3.9 \pm 0.9$ & $3.7 \pm 0.9$ & 0.099 \\
\hline
\end{tabular}

Abbreviations: PMDD, premenstrual dysphoric disorder; PMS, premenstrual syndrome; SD, standard deviation.

*Analysis of variance (ANOVA) was used to compare and test the equality of the means between the groups. Pairwise comparisons were performed using the Tukey method. In both tests, we used the significance level of $5 \%(p<0.05)$.

depressive and anxiety disorders, irritable bowel syndrome, and thyroid diseases, which can be similar to PMDD. ${ }^{4}$

Halbreich et $\mathrm{al}^{2}$ suggest that the prevalence of clinicallyrelevant PMS/PMDD is higher than the widely-cited estimates. In our study, 26.6\% of the students had PMDD, according to the DSM-5 criteria. ${ }^{5}$ This percentage is higher than in other studies in which the prevalence varied from 5.9 to $14.2 \%{ }^{3,13,21,24}$ However, in medical students in Nigeria, 25 the prevalence of PMDD was $36.1 \%$, which is higher than in our study. The reason for this high rate might be associated with a tendency to amplify the recall of symptoms' severity and frequency by these students. ${ }^{23,25}$ It is also known that there are many symptoms produced by psychological illnesses that may confound the symptoms of PMDD, among which premenstrual exacerbation of some underlying psychiatric disorders as referred by Issa et al. ${ }^{25}$

Overall, the students with PMS had a lower quality of life score in all domains compared to those who did not have the syndrome, which is similar to other studies. ${ }^{7,8,21,22,24}$ This could be due to the fact that the symptoms of PMS are very diverse and can affect several aspects of a woman's life. Both the physical and emotional symptoms can limit daily life activities and decrease the perception of quality of life, which may have been reflected in the questions about the selfperception of quality of life.

The physical domain showed a statistically significant difference between women who did not have PMS and those who had some form of the syndrome, which is in agreement with the literature in which it is reported that women's daily life activities are associated with PMS symptoms, such as pain, discomfort, and fatigue, ${ }^{7,24}$ and increases in school absenteeism. ${ }^{26}$

Regarding the mental domain, which includes self-esteem, body image, spirituality, and negative feelings, ${ }^{11}$ a statistically significant difference was observed between the women without PMS and those with both forms: that is, mild PMS and PMDD. Our findings are similar to those of other studies. $^{7,21,24,27}$ The interaction of the central nervous system with cyclical hormonal changes is a destabilizing factor in women with PMS. ${ }^{28}$ Veras et $\mathrm{al}^{28}$ also verified that the majority of women with PMS develop depressive symptoms that interfere with their interpersonal relationships.
As for the domain of social relationships, there was a difference between women without PMS and those with mild PMS, which is in line with the findings of Muramatsu et al, ${ }^{12}$ who found that irritability and relational conflicts are reported the most by women with PMS. Women with PMS seem to have a greater tendency to seek isolation, distancing themselves from family and marital support. ${ }^{12}$

There was also a difference between those with and without PMS in the environmental domain, which is similar to the studies performed in Turkey $^{29}$ and in Iran, ${ }^{21}$ which associated the presence of PMS to lower quality of life scores in the environmental domain. A study conducted in Brazil emphasized that the "health and social care" facet was the most significant within the environmental domain, which reflects the users' dissatisfaction regarding the availability and quality of the health services offered to them. ${ }^{7}$

Our findings have some limitations because the population of this study was students from health-related areas, which does not represent the population of women in general.

As this was a cross sectional study based on retrospective symptoms recall, there could have had problems with recall bias and the data could differ from data collected prospectively that evaluate each cycle for at least 2 or 3 months according to criteria statements ${ }^{4,30}$ In addition, the students were not assessed for other possible differential diagnoses and this could lead to overdiagnosis of the condition.

However, the higher prevalence of PMS among university students in health-related courses and its effect on their quality of life suggest the necessity to implement educational practices that inform women about the syndrome since, once informed, women will be more likely to seek treatment, thereby reducing the incidence of the syndrome and its negative influence on quality of life.

\section{Conclusion}

Mild PMS and PMDD are prevalent among university students in health-related courses, and the syndrome can affect the students' self-assessment in all the domains of quality of life. 


\section{Contributions}

F. F. Victor, A. I. Souza, F. A. C. Silva, and A. L. C. G. Ferreira contributed to the conception and design, analysis, interpretation of the data, and writing of the article. F. F. Victor, C. B. T. Barreiros, and J. L. N. Barros contributed to the data collection, analysis, and writing of the article. A. I. Souza and A. L. C. G. Ferreira also contributed to the critical review of the intellectual content. All the authors have approved the final version to be published.

\section{Conflicts of Interest}

The authors have no conflicts of interest to declare.

\section{Acknowledgments}

We would like to thank Programa Institucional de Bolsas de Iniciação Científica Conselho Nacional de Desenvolvimento Científico e Tecnológico do Instituto de Medicina Integral Professor Fernando Figueira (CNPq/IMIP 2016/ 2017; process number: 114792/2016-0).

\section{References}

1 Yela DA. Federação Brasileira de Associações de Ginecologia e Obstetrícia (FEBRASGO), Comissão Nacional Especializada em Ginecologia Endócrina. Tensão Pré-Menstrual - Critérios para Diagnóstico. 2018https://www.febrasgo.org.br/pt/noticias/item/422-tensao-premenstrual-criterios-para-diagnostico. Accessed March 20, 2018

2 Halbreich U, Borenstein J, Pearlstein T, Kahn LS. The prevalence, impairment, impact, and burden of premenstrual dysphoric disorder (PMS/PMDD). Psychoneuroendocrinology 2003;28(Suppl 3):1-23. Doi: 10.1016/S0306-4530(03)00098-2

3 Hamaideh SH, Al-Ashram SA, Al-Modallal H. Premenstrual syndrome and premenstrual dysphoric disorder among Jordanian women. J Psychiatr Ment Health Nurs 2014;21(01):60-68. Doi: 10.1111/jpm. 12047

4 American College of Obstetricians and Gynecologists. Premenstrual Syndrome. 2015https://www.acog.org/Patients/FAQs/Premenstrual -Syndrome-PMS. Accessed July 28, 2017

5 American Psychiatric Association. Depressive Disorders. In: American Psychiatric Association. Diagnostic and Statistical Manual of Mental Disorders: DSM-5. 5th ed. Arlington, VA: American Psychiatry Association; 2013:948

6 Demarque R, Rennó J Jr, Lobo Ribeiro $\mathrm{H}$, et al. [Premenstrual dysphoric disorder: brief review]. Rev Debates Psiquiatr 2013;3:6-13

7 Maia MS, Aguiar MIF, Chaves ES, Rolim ILTP. Quality of life of women with premenstrual syndrome from the scale WHOQOLBREF. Ciênc Cuid Saúde 2014;13(02):236-244. Doi: 10.4025/ cienccuidsaude.v13i2.15759

8 Sahin S, Ozdemir K, Unsal A. Evaluation of premenstrual syndrome and quality of life in university students. J Pak Med Assoc 2014;64(08):915-922

9 Pereira E, Teixeira CS, Santos A. [Quality of life: approaches, concepts and assessment]. Rev Bras Educ Fís Esporte 2012;26 (02):241-250. Doi: 10.1590/S1807-55092012000200007

10 Silva CML, Gigante DP, Minten GC. Premenstrual symptoms and syndrome according to age at menarche in a 1982 birth cohort in southern Brazil. Cad Saude Publica 2008;24(04):835-844. Doi: $10.1590 /$ S0102-311 × 2008000400014

11 Fleck MPA, Louzada S, Xavier M, et al. [Application of the Portuguese version of the abbreviated instrument of quality life WHOQOL-bref]. Rev Saude Publica 2000;34(02):178-183. Doi: $10.1590 /$ S0034-89102000000200012
12 Muramatsu CH, Vieira OCS, Simões CC, Katayama DA, Nakagawa $\mathrm{FH}$. [Consequences of the premenstrual stress syndrome in women's life]. Rev Esc Enferm USP 2001;35(03):205-213. Doi: $10.1590 /$ S0080-62342001000300002

13 Carvalho VCP, Cantilino A, Gonçalves CRK, Moura RT, Sougey EB. Prevalência da síndrome de tensão pré-menstrual e do transtorno disfórico pré-menstrual entre estudantes universitárias. Neurobiologia 2010;73:41-53

14 Antunes G, Rico VV, Gouveia A Jr. [Changes of mood and anxiety during the menstrual cycle with use of oral contraceptives]. Interação Psicol 2004;1(08):79-84. Doi: 10.5380/psi.v8i1.3241

15 Bianco SM, Barancelli L, Roveda AK, Santin JC. [Influence of the menstrual cycle on depressive episodes]. Arq Ciênc Saúde UNIPAR 2004;8(01):11-17. Doi: 10.25110/arqsaude.v8i1.2004.236

16 Brilhante AVM, Bilhar APM, Carvalho CB, Karbage SAL, Pequeno Filho EP, Rocha ES. [Premenstrual syndrome and premenstrual dysphoric syndrome: current aspects]. Femina 2010;38:373-378

17 Drosdzol A, Nowosielski K, Skrzypulec V, Plinta R. Premenstrual disorders in Polish adolescent girls: prevalence and risk factors. J Obstet Gynaecol Res 2011;37(09):1216-1221. Doi: 10.1111/ j.1447-0756.2010.01505.x

18 Lustyk MKB, Widman L, Paschane A, Ecker E. Stress, quality of life and physical activity in women with varying degrees of premenstrual symptomatology. Women Health 2004;39(03):35-44. Doi: 10.1300/J013v39n03_03

19 Teixeira ALS, Oliveira ECM, Dias MRC. [Relationship between the level of physical activity and premenstrual syndrome incidence]. Rev Bras Ginecol Obstet 2013;35(05):210-214. Doi: 10.1590/ S0100-72032013000500004

20 Cheng SH, Shih CC, Yang YK, Chen KT, Chang YH, Yang YC. Factors associated with premenstrual syndrome - a survey of new female university students. Kaohsiung J Med Sci 2013;29(02):100-105. Doi: 10.1016/j.kjms.2012.08.017

21 Farrokh-Eslamlou H, Oshnouei S, Heshmatian B, Akbari E. Premenstrual syndrome and quality of life in Iranian medical students. Sex Reprod Healthc 2015;6(01):23-27. Doi: 10.1016/j.srhc.2014.06.009

22 Delara M, Ghofranipour F, Azadfallah P, Tavafian SS, Kazemnejad A, Montazeri A. Health related quality of life among adolescents with premenstrual disorders: a cross sectional study. Health Qual Life Outcomes 2012;10:1. Doi: 10.1186/1477-7525-10-1

23 Yonkers KA, Simoni MK. Premenstrual disorders. Am J Obstet Gynecol 2018;218(01):68-74. Doi: 10.1016/j.ajog.2017.05.045

24 Al-Batanony MA, AL-Nohair SF. Prevalence of premenstrual syndrome and its impact on quality of life among University Medical Students, Al Qassim University, KSA. Public Health Res. 2014;4 (01):1-6. Doi: 10.5923/j.phr.20140401.01

25 Issa BA, Yussuf AD, Olatinwo AWO, Ighodalo M. Premenstrual dysphoric disorder among medical students of a Nigerian university. Ann Afr Med 2010;9(03):118-122. Doi: 10.4103/1596-3519.68354

26 Potur DC, Bilgin NC, Komurcu N. Prevalence of dysmenorrhea in university students in Turkey: effect on daily activities and evaluation of different pain management methods. Pain Manag Nurs 2014;15(04):768-777. Doi: 10.1016/j.pmn.2013.07.012

27 Yang M, Wallenstein G, Hagan M, Guo A, Chang J, Kornstein S. Burden of premenstrual dysphoric disorder on health-related quality of life. J Womens Health (Larchmt) 2008;17(01): 113-121. Doi: 10.1089/jwh.2007.0417

28 Veras AB, Nardi AE. Female sexual hormones and mood disorders. J Bras Psiquiatr 2005;54:57-68

29 Pinar G, Colak M, Oksuz E. Premenstrual Syndrome in Turkish college students and its effects on life quality. Sex Reprod Healthc 2011;2(01):21-27. Doi: 10.1016/j.srhc.2010.10.001

30 Borenstein JE, Dean BB, Leifke E, Korner P, Yonkers KA. Differences in symptom scores and health outcomes in premenstrual syndrome. J Womens Health (Larchmt) 2007;16(08):1139-1144. Doi: $10.1089 /$ jwh.2006.0230 